\title{
TEACHER EDUCATION STUDENTS' SELF-ASSESSMENT OF COMPETENCE FOR COOPERATION WITH PARENTS
}

\author{
Marina Đuranović \\ Faculty of Teacher Education, University of Zagreb, Croatia \\ Siniša Opić \\ Faculty of Teacher Education, University of Zagreb, Croatia \\ Irena Klasnić \\ Faculty of Teacher Education, University of Zagreb, Croatia
}

\begin{abstract}
To be a teacher in the times of today is a great challenge. In order to respond to the needs of modern society, lifelong learning and mastery of numerous competences are expected of the teacher in various fields of work, wherein cooperation with parents is one of the extremely important areas. The goal of the research was to gain insight into self-assessment of competence of students at the Faculty of Teachers Education for future cooperation with parents. The research was implemented during October, 2020, on the sample of 416 students in their first, third and fifth year at the Faculty of Teacher Education of the University of Zagreb (Croatia). It is a futurological research for whose needs a questionnaire was designed with 26 manifest variables on an ordinal, five-degree Likert-type scale. From the manifest set of variables of competence for future cooperation with parents, three composite variables were formed: general cooperation competence, competence for cooperation directed to teaching efficacy, and competence for cooperation directed to communication with parents. The results show that the total student self-assessment of competences for future cooperation with parents is relatively positive, and the existence of statistically significant differences in all three composite variables. Faculties educating future teachers should introduce obligatory courses which would sensitise and capacitate them for future cooperation with parents.
\end{abstract}

Keywords: communication; competences; cooperation; parents; students; teaching efficacy.

\section{Introduction}

Being a teacher is a great challenge today. In order to respond to the needs of contemporary society, lifelong learning and mastery of numerous competences in various fields of his/her work is expected of the teacher. One of the exceptionally important areas of teacher's work and profession is also cooperation with parents. Contemporary society we live in has imposed new goals and challenges in all areas of human activity (business, politics, economy), the field of education not being the exception. The teaching profession is becoming more 
and more demanding and complex each day. The competence profile of the teacher has undergone a significant transformation. In order for the today's teacher to perform the work successfully, he/she needs numerous competences. Scientific and expert literature entails various explanations of the term competence. Cindrić, Miljković, and Strugar (2010, p. 216) define competence as a combination of knowledge, abilities and skills indispensable for a certain context. Competences are: knowledge and understanding (theoretical knowledge and the capacity for cognition and understanding); knowledge on how to act (practical application of knowledge in a certain context), and knowledge on how to be (values as an integral part of the ways of perceiving and living with others and oneself in the social context). Blažević (2016) warns that the use of a multidisciplinary approach (pedagogy, psychology, communicology, etc.) is essential in defining teaching competences which are encompassed by a wide scope, spanning from those very broad and general (fundamental) to the very specific and expert ones. Jurčić (2012) defines teacher's competence as an expertise based on knowledge, abilities and values. The mentioned author underscore that teaching competences need to be observed as interwoven in the fundamental areas of teacher's work:

- $\quad$ the methodology for designing the teaching curricula;

- $\quad$ organising and guiding the education process;

- forming classroom climate;

- $\quad$ determining the student's achievement;

- cooperation with parents.

Significant number of researchers remarks the teacher's ability to maintain and sustain quality relationships with parents as one of the basic characteristics a competent teacher (Rečić, 2006; Kostović-Vranješ \& Ljubetić, 2008; Ljubetić \& Zadro, 2009; Zrilić \& Marin, 2019). The concept of teacher-parent cooperation entails the process of mutual briefing, agreement, counselling and joint learning, with the goal of sharing utual responsibility for the child's development in the family and school (Maleš, 1996). Epstein (2001) states six types of parental involvement in school:

- parenting - it concerns stimulating the family environment as one of the prerequisites for the child's success in school;

- communication - it entails efficient school-family and family-school communication;

- $\quad$ volunteering - parents' inclusion in various school activities;

- learning at home - capacitating parents for helping children in doing homework;

- $\quad$ making decisions - motivating parents to cooperate in making school decisions by means of their representatives;

- cooperation with the community - cooperation between the local community and school in the best interest of children. 
LaRocque, Kleiman and Darling state similar types (2011):

- $\quad$ volunteering at school;

- $\quad$ helping children with their homework;

- $\quad$ attending school functions;

- $\quad$ visiting the child's classroom;

- $\quad$ sharing expertise or experience with the class through guest speaking;

- taking on leadership roles in the school and participating in the decision-making process.

It is expected of the school to develop cooperative relationships with the family; its responsibility ensues from the fact that cooperation begins in school spaces and from the expectations of the teacher as a professional to know how to motivate parents for cooperation (Maleš, 2015).

The question arises as to why it is important to realise quality cooperation with parents. Numerous researches name various benefits for the welfare of children/students: parental involvement in school and school activities is positively correlated with students' academic achievement (Epstein, 1994; Hill \& Taylor, 2004; Burcu \& Sungur, 2009; Jeynes, 2012), with students' attendance and participation in classes (Fan \& Williams, 2010; Avvisati, Gurgand, Guyon, \& Maurin, 2014), with appropriate (good) behaviour (Domina, 2005; Sheridan et al., 2017), and better relationships with other students in class (Garbacz, Zerr, Dishion, Seeley, \& Stormshak, 2018). Furthermore, when parents are actively engaged in school, children are more satisfied with it (Hiatt-Michael, 2001), which positively affects their mental health (Wang \& Sheikh-Khalil, 2014). Shu (2019) stresses that the communication between school and parents is the key to realising mutual quality relationships. Besides being beneficial for students, parents' inclusion in school brings gain to the parents as well as teachers. The inclusion of parents in school facilitates teaching and empowers teachers to meet the students' needs more easily. Considering the fact that quality cooperation between parents and teachers and active parental participation in the school's functioning has numerous benefits, it is important to design ways and capacitate future teachers for increasing parents' involvement in school and the realisation of quality communication. Although the importance of preparing future teachers for cooperation with parents has been recognised long ago, students, future teachers, express their worries about the possibilities of realising positive and pleasant relationships between teachers and parents (Baum \& McMurraySchwarz, 2004). 
Đuranović et al., 2021. Teacher Education Students' Self-Assessment of Competence for Cooperation with Parents

\section{Methodology}

The goal of the research was to gain insight into the self-assessment of competence for future cooperation with parents of students at the Faculty of Teacher Education.

It is a futurological research whose design utilised the quantitative approach. The research was implemented in October 2020, on a sample of 416 students of the first $(n=132)$, third $(n=151)$ and fifth $(n=133)$ year of the Faculty of Teacher Education of the University of Zagreb (Croatia). Since only few students were males, gender was not considered. The participants were informed on their right to withdraw from the research at any given time, and that the gathered data are anonimous, confidential, and intended exclusively for the needs of the research.

The questionnaire was designed on the basis of the studied literature and research dealing with similar issues (Alaçam, \& Olgan, 2017; Cheung \& Kam, 2019; Shu, 2019). A questionnaire was designed for the needs of the research with 26 manifest variables on an ordinal five-degree Likert scale, wherein the quantifiers are: 1 - it is not at all true for me; $2-$ it is somewhat not true for me; 3 - it is neither true nor false for me; 4 - it is true for me in greater measure; 5 - it is completely true for me. To check the intelligibility and suitability of the questionnaire, the instrument had been field tested in a pilot research implemented with 20 students who were not involved in the main research. The questionnaire was altered in accordance with the recommendations, and the main research utilised the revised version. It took 15 minutes to fill in the questionnaire with the paper-pencil method.

The following hypotheses were set:

H 1 - there is a statistically significant difference in the students' selfassessment of competence for future cooperation with parents: general cooperation competence, competence for cooperation directed to teaching efficacy, and competence for cooperation directed to communication with parents.

H 2 - there is a statistically significant difference in all three composite variables in the student self-assessment of competences for future cooperation with parents regarding the year of study.

\section{Results and Biscussion}

The obtained data were processed with the use of SPSS 26.0 statistical package (Statistical Package for the Social Sciences).

For the needs of this work, from the manifest set of variables of competences for future cooperation with parents, three composite variables were formed: general cooperation competence, competence for cooperation directed to teaching 
Proceedings of the International Scientific Conference. Volume I, May $28^{\text {th }}-29^{\text {th }}$, 2021. 105-118 efficacy, and competence for cooperation directed to communication with parents (Table 1).

Table 1 Examples of the Manifest Variables Included in the Composite Variables

\begin{tabular}{|c|c|}
\hline COMPOSITE VARIABLES & $\begin{array}{l}\text { EXAMPLES OF THE MANIFEST } \\
\text { VARIABLES }\end{array}$ \\
\hline general cooperation competence & $\begin{array}{c}\text { My relationship with parents will improve if I } \\
\text { cooperate with them intensively. } \\
\text { I don't fear cooperation with parents. }\end{array}$ \\
\hline $\begin{array}{l}\text { competence for cooperation directed to } \\
\text { teaching efficacy }\end{array}$ & $\begin{array}{l}\text { Students will have better achievements if I } \\
\text { cooperate with parents. } \\
\text { I feel I will be able to motivate parents to } \\
\text { participate in class as guest-speakers. }\end{array}$ \\
\hline $\begin{array}{l}\text { competence for cooperation directed to } \\
\text { communication with parents }\end{array}$ & $\begin{array}{c}\text { Holding a parent-teacher meeting will not be } \\
\text { a problem for me. } \\
\text { I feel I will be able to successfully } \\
\text { communicate with parents in the virtual } \\
\text { environment. }\end{array}$ \\
\hline
\end{tabular}

Descriptive values of the composite variables are presented in Table 2.

Table 2 Descriptive Statistics for the Composite Variables

\begin{tabular}{|c|c|c|c|c|c|c|c|c|c|}
\hline & $\mathrm{N}$ & Min & Max & Mean & $\begin{array}{l}\text { Std. } \\
\text { Dev. }\end{array}$ & Skev & ness & Kurt & tosis \\
\hline & Stat. & Stat. & Stat. & Stat. & Stat. & & $\begin{array}{l}\text { Std. } \\
\text { Error }\end{array}$ & Stat. & $\begin{array}{l}\text { Std. } \\
\text { Error }\end{array}$ \\
\hline $\begin{array}{l}\text { general cooperation } \\
\text { competence (E 1) }\end{array}$ & 416 & 2,17 & 5,00 & 3,6034 & ,48753 & ,006 & ,120 &,- 222 & ,239 \\
\hline $\begin{array}{l}\text { competence for } \\
\text { cooperation directed to } \\
\text { teaching efficacy (E 2) }\end{array}$ & 415 & 2,50 & 5,00 & 4,1364 & ,49157 &,- 481 & 120 &,- 170 & ,239 \\
\hline $\begin{array}{l}\text { competence for } \\
\text { cooperation directed to } \\
\text { communication with } \\
\text { parents (E 3) }\end{array}$ & 416 & 1,50 & 5,00 & 3,8277 &, 56014 &,- 422 & 120 & ,749 & ,239 \\
\hline valid N (list wise) & 415 & & & & & & & & \\
\hline
\end{tabular}

As visible from Table 2, E1 and E2 have asymetrical sampling distributions according to the scale's direction, i.e. higher mean values. Composite variables E1 and E2 are mildly platicurtic, while E3 is mildly leptocurtic. Variability coefficient is $<35 \%$, which indicates homogenous characteristics. 
Đuranović et al., 2021. Teacher Education Students' Self-Assessment of Competence for Cooperation with Parents

$H 1$ - there is a statistically significant difference in the students' selfassessment of competence for future cooperation with parents: general cooperation competence, competence for cooperation directed to teaching efficacy, and competence for cooperation directed to communication with parents.

H1 hypothesis is tested in the general linear model. The results of multivariate tests (within subject design estimation) are shown in Table 3.

Table 3 Multivariate Tests

\begin{tabular}{l|l|c|c|c|c|c}
\multicolumn{2}{l|}{} & & & Hypothesis & & \\
Effect & Value & F & df & Error df & Sig. \\
\hline ESTIMATION & Pillai's Trace &, 559 & $262,185^{\mathrm{b}}$ & 2,000 & 413,000 &, 000 \\
\cline { 2 - 7 } & Wilks' Lambda &, 441 & $262,185^{\mathrm{b}}$ & 2,000 & 413,000 &, 000 \\
\cline { 2 - 8 } & Hotelling's Trace & 1,270 & $262,185^{\mathrm{b}}$ & 2,000 & 413,000 &, 000 \\
\cline { 2 - 7 } & Roy's Largest Root & 1,270 & $262,185^{\mathrm{b}}$ & 2,000 & 413,000 &, 000 \\
\hline
\end{tabular}

Maulchy`s W test of sphericity is statistically significant $(\mathrm{W}=0,908$; $\mathrm{df}=2$; Chi square/approx $=39.847 ; \quad \mathrm{p}=0,000)$. Thus, Greenhouse-Geisser $(\mathrm{df}=1,832 ; \mathrm{F}=200.297 ; \mathrm{p}=0,000)$ and Huynh-Feldt $(\mathrm{df}=1,839 ; \mathrm{F}=200,927$; $\mathrm{p}=0,000$ ) are used as tests of within-subject effects. Hence, the difference between assessment of values of the cooperation with parents competence is obtained. For better understanding the differences between the composite variables of cooperation competence, the pairwise comparison on the estimated marginal means was done (Table 4).

Table 4 Pairwise Comparisons

(I)

(J) Mean Std.

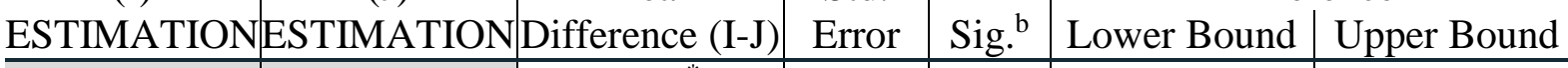

\begin{tabular}{c|c|c|c|c|c|c}
\hline \multirow{2}{*}{1} & 2 &,$- 532^{*}$ &, 023 & $\mathbf{, 0 0 0}$ &,- 578 &,- 486 \\
\cline { 2 - 7 } & 3 &,$- 224^{*}$ &, 026 & $\mathbf{, 0 0 0}$ &,- 275 &,- 174 \\
\hline \multirow{2}{*}{2} & 1 &, $532^{*}$ &, 023 & $\mathbf{, 0 0 0}$ &, 486 &, 578 \\
& 3 &, $308^{*}$ &, 030 & $\mathbf{, 0 0 0}$ &, 248 &, 367 \\
\hline \multirow{2}{*}{3} & 1 &, $224^{*}$ &, 026 & $\mathbf{, 0 0 0}$ &, 174 &, 275 \\
& 2 &,$- 308^{*}$ &, 030 & $\mathbf{, 0 0 0}$ &,- 367 &,- 248 \\
\hline
\end{tabular}

Based on estimated marginal means

*. The mean difference is significant at the, 05 level.

b. Adjustment for multiple comparisons: Least Significant Difference (equivalent to no adjustments). 
As show in Table 4, statistically significant differences were determined between all pairs of composite variables of assessment of competence for future cooperation. Figure 1 presents new estimated marginal means of the composite variables.

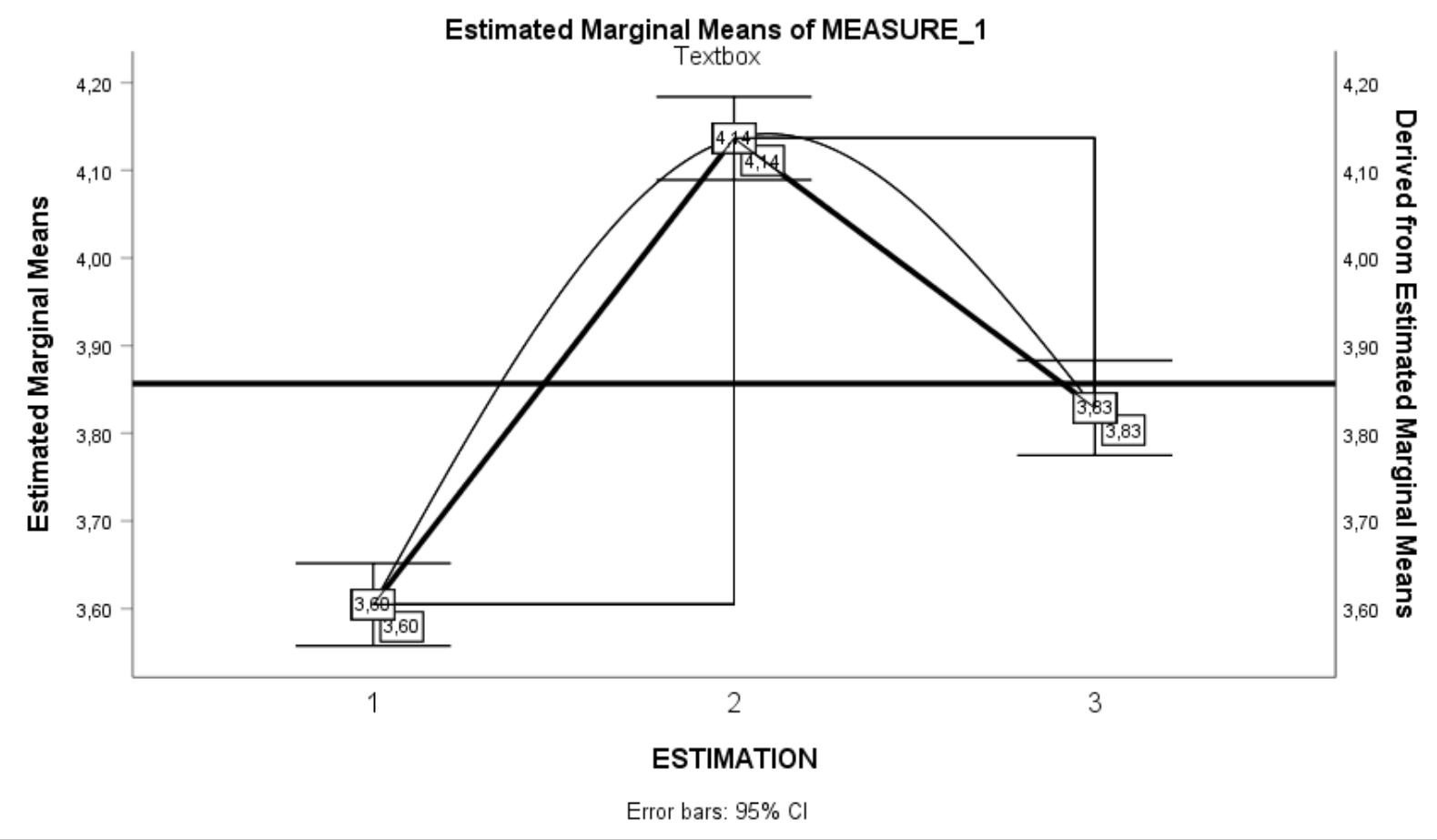

Figure 1 E 1 - General Cooperation Competence; E 2 - Competence for Cooperation Directed to Teaching efficacy; $\mathrm{E} 3$ - Competence for Cooperation Directed to Communication with Parents

Therefore, overall assessment of competences for future cooperation with parents is relatively positive (grand estimated mean), and students from the sample attribute the highest assessment to competence directed to teaching efficacy. In accordance, hypothesis H1 is confirmed, i.e. there is a statistically significant difference in the students' self-assessment of competences for future cooperation with parents: general cooperation competence, competence for cooperation directed to teaching efficacy, and competence for cooperation directed to communication with parents.

Tichenor (1998) came to similar results in examining students' standpoints in her research. The students evaluated general cooperation with parents as fairly positive.

In our research, the students, future teachers, assess themselves as most competent for realising cooperation directed to teaching efficacy. The reason for such finding could be large number of courses (pedagogical-psychologicaldidactical-methodical) with the learning outcomes directed precisely to teaching 
Đuranović et al., 2021. Teacher Education Students' Self-Assessment of Competence for Cooperation with Parents

future pupils. Unfortunately, no obligatory course for students of teacher education exists that would be directed exclusively to gaining the competence for cooperation with parents (but is realised within other courses or in the frame of elective courses).

Ljubetić and Zadro (2009) have done a research with the goal of determining the extent to which teachers find themselves competent for the work with parents. According to the obtained results, most teachers who participated in the research consider themselves inadequately competent in the area and have pointed out that a lot more attention needs to be directed to preparing students for the work with parents in the course of their studies (58\% claims this to be completely true, while $42 \%$ claims it to be partially true).

H 2 - there is a statistically significant difference in all three composite variables in the student self-assessment of competences for future cooperation with parents regarding the year of study.

The distribution of independent variable study year is as follows: 132 firstyear students (31,7\%), 151 third-year students (36,3\%), and 133 fifth-year students (32\%).

ANOVA one-way variance analysis was used for testing the $\mathrm{H} 2$, and the results are presented in Table 5.

Table 5 ANOVA

\begin{tabular}{|c|c|c|c|c|c|c|}
\hline & & $\begin{array}{l}\text { Sum of } \\
\text { Squares }\end{array}$ & df & $\begin{array}{c}\text { Mean } \\
\text { Square } \\
\end{array}$ & $\mathrm{F}$ & Sig. \\
\hline \multirow[t]{3}{*}{$\begin{array}{c}\text { general cooperation } \\
\text { competence (E 1) }\end{array}$} & $\begin{array}{l}\text { Between } \\
\text { groups }\end{array}$ & 2,057 & 2 & 1,029 & 4,400 & ,013 \\
\hline & Within Groups & 96,310 & 412 & ,234 & & \\
\hline & Total & 98,368 & 414 & & & \\
\hline \multirow{3}{*}{$\begin{array}{l}\text { competence for cooperation } \\
\text { directed to teaching efficacy } \\
\text { (E 2) }\end{array}$} & $\begin{array}{l}\text { Between } \\
\text { Groups }\end{array}$ & ,693 & 2 & ,346 & 1,436 & ,239 \\
\hline & Within Groups & 99,347 & 412 & ,241 & & \\
\hline & Total & 100,039 & 414 & & & \\
\hline \multirow{3}{*}{$\begin{array}{l}\text { competence for cooperation } \\
\text { directed to communication } \\
\text { with parents (E 3) }\end{array}$} & $\begin{array}{l}\text { Between } \\
\text { Groups }\end{array}$ & 9,908 & 2 & 4,954 & 17,001 & ,000 \\
\hline & Within Groups & 120,056 & 412 & ,291 & & \\
\hline & Total & 129,964 & 414 & & & \\
\hline
\end{tabular}


The results of the Levene test indicate the homogenous variances of dependent variables across the compared subsamples $(\mathrm{p}>0,05)$. In accordance with the results of the ANOVA, a statistically significant difference was confirmed between students at different study years (first, third and fifth) in their self-assessment of competences for the future cooperation on two composite variables: general cooperation competence and competence for cooperation directed to communication with parents.

Post hoc analysis, i.e. Gabriel test of multiple comparison, was implemented additionally (Table 6).

Table 6 Gabriel Test of Multiple Comparisons

\begin{tabular}{|c|c|c|c|c|c|c|c|}
\hline \multirow[b]{2}{*}{ Dependent Variable } & \multirow[b]{2}{*}{$\begin{array}{l}\text { (I) year } \\
\text { of study }\end{array}$} & \multirow[b]{2}{*}{$\begin{array}{l}\text { (J) year of } \\
\text { study }\end{array}$} & \multirow{2}{*}{$\begin{array}{l}\text { Mean } \\
\text { Difference } \\
\text { (I-J) }\end{array}$} & \multirow[b]{2}{*}{$\begin{array}{l}\text { Std. } \\
\text { Error }\end{array}$} & \multirow[b]{2}{*}{ Sig. } & \multicolumn{2}{|c|}{$\begin{array}{c}95 \% \\
\text { Confidence } \\
\text { Interval }\end{array}$} \\
\hline & & & & & & $\begin{array}{l}\text { Lower } \\
\text { Bound }\end{array}$ & $\begin{array}{l}\text { Upper } \\
\text { Bound }\end{array}$ \\
\hline \multirow[t]{6}{*}{$\begin{array}{l}\text { general cooperation } \\
\text { competence }\end{array}$} & \multirow[t]{2}{*}{$\begin{array}{l}\text { First } \\
\text { year }\end{array}$} & $\begin{array}{l}\text { Third } \\
\text { year }\end{array}$ & ,15031* & ,05761 & ,028 & ,0123 & ,2883 \\
\hline & & Fifth year &, $15215^{*}$ & ,05951 & ,032 & ,0095 & ,2948 \\
\hline & \multirow{2}{*}{$\begin{array}{l}\text { Third } \\
\text { year }\end{array}$} & First year &,$- 15031^{*}$ & ,05761 & ,028 &,- 2883 &,- 0123 \\
\hline & & Fifth year & 00184 & 05761 & 1,000 &,- 1362 & 1399 \\
\hline & \multirow{2}{*}{$\begin{array}{l}\text { Fifth } \\
\text { year }\end{array}$} & First year &,$- 15215^{*}$ & 05951 & 032 &,- 2948 &,- 0095 \\
\hline & & Third year &,- 00184 & , 05761 & 1,000 &,- 1399 & ,1362 \\
\hline \multirow{6}{*}{$\begin{array}{l}\text { competence for } \\
\text { cooperation directed to } \\
\text { communication with } \\
\text { parents }\end{array}$} & \multirow[t]{2}{*}{$\begin{array}{l}\text { First } \\
\text { year }\end{array}$} & $\begin{array}{l}\text { Third } \\
\text { year }\end{array}$ & ,30469* & ,06432 & ,000 & ,1506 & ,4588 \\
\hline & & Fifth year & ,35606 & ,06645 & ,000 & ,1968 & ,5153 \\
\hline & \multirow{2}{*}{$\begin{array}{l}\text { Third } \\
\text { year }\end{array}$} & First year &,$- 30469^{*}$ & ,06432 & ,000 &,- 4588 &,- 1506 \\
\hline & & Fifth year & 05137 & ,06432 & ,809 &,- 1027 & ,2055 \\
\hline & \multirow{2}{*}{$\begin{array}{l}\text { Fifth } \\
\text { year }\end{array}$} & First year &,$- 35606^{*}$ & 06645 & ,000 &,- 5153 &,- 1968 \\
\hline & & Third year &,- 05137 & ,06432 & ,809 &,- 2055 & 1027 \\
\hline
\end{tabular}

*. The mean difference is significant at the 0.05 level.

In line with the results of the Gabriel test, differences on both composite variables are confirmed, wherein the first-year students have statistically significant, higher assessment of competence for cooperation with parents than the third- and fifth-year students (additionally, Figure 2). 
Đuranović et al., 2021. Teacher Education Students' Self-Assessment of Competence for Cooperation with Parents
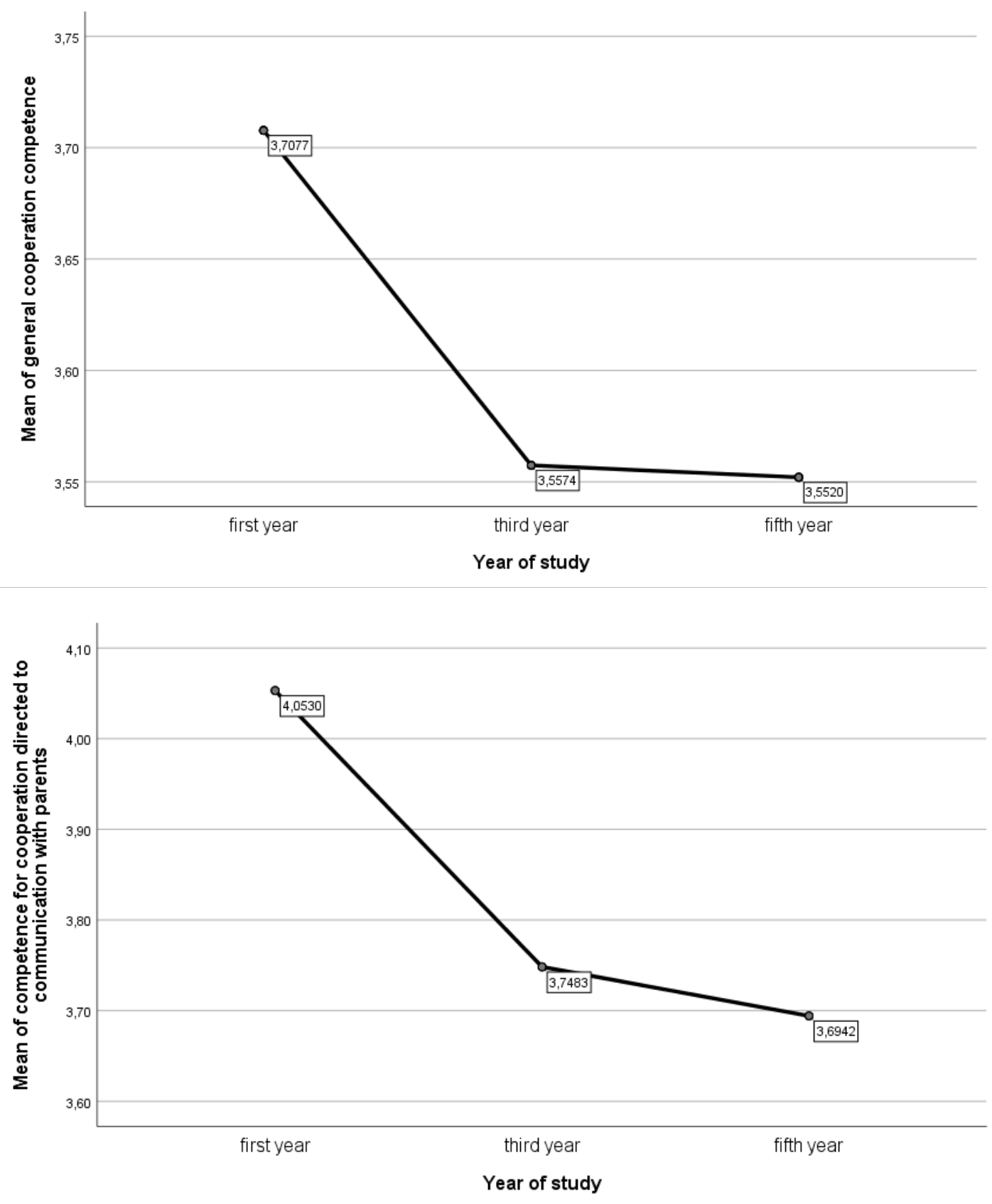

Figure 2 Mean Values between the Subsamples on the Composite Variables

Additionally, Bayesian estimates of coefficients for the composite variables confirmed the difference in the subsamples (Tables 7a and 7b). 
Table 7a Bayesian Estimates of Coefficients ${ }^{a, b, c}$

\begin{tabular}{c|c|c|c|c|c} 
& \multicolumn{3}{|c|}{ Posterior } & \multicolumn{2}{c}{ 95\% Credible Interval } \\
Parameter & Mode & Mean & Variance & Lower Bound & Upper Bound \\
\hline Year of study = first year & 3,708 & 3,708 &, 002 & 3,625 & 3,790 \\
\hline Year of study = third year & 3,557 & 3,557 &, 002 & 3,480 & 3,635 \\
\hline Year of study = fifth year & 3,552 & 3,552 &, 002 & 3,470 & 3,634 \\
\hline
\end{tabular}

a. Dependent variable: about cooperation in general

b. Model: year of study

c. Assume standard reference priors.

\begin{tabular}{c|c|c|c|c|c}
\multicolumn{7}{c}{ Table 7b Bayesian Estimates of Coefficients } \\
& \multicolumn{3}{|c|}{ Pos, } \\
Parameter & Mode & Mean & Variance & Lower Bound & Upper Bound \\
\hline Year of study= first year & 4,053 & 4,053 &, 002 & 3,961 & 4,145 \\
\hline Year of study = third year & 3,748 & 3,748 &, 002 & 3,662 & 3,835 \\
\hline Year of study = fifth year & 3,694 & 3,694 &, 002 & 3,602 & 3,786 \\
\hline
\end{tabular}

a. Dependent variable: communication with parents

b. Model: year of study

c. Assume standard reference priors.

In accordance with the results, $\mathrm{H} 2$ hypothesis is partially confirmed.

A possible explanation of such finding could be that the first-year students assess their general cooperation competence and the competence for cooperation directed to communication with parents as higher because at the onset of their studies they are not fully acquainted with the complexity of the teaching profession. Pendergast, Garvis and Keogh (2011) have done a longitudinal research on the Australian students', future teachers', standpoints about what being a teacher entails. It appears that the students had overestimated their level of teacher self-efficacy at the beginning of their study, before acquiring practical experience, more than they have during the final semester of their teacher education programs. Alaçam and Olgan (2017) emphasize that preservice teachers are unaware of the problems concerning parent involvement in education.

\section{Conclusions}

Educating and raising children is neither simple nor easy. This demanding task is shared between parents and teachers with the same goal, namely their quality mutual relations and cooperation for the purpose of children's/students' welfare. A life role for parents is a professional one for teachers. Defining roles 
Đuranović et al., 2021. Teacher Education Students' Self-Assessment of Competence for Cooperation with Parents

and setting clear goals are prerequisites for quality cooperation filled with mutual understanding, respect and appreciation (Ljubetić \& Zadro, 2009).

Realising positive cooperation and healthy communication between teachers and parents already at the start of education greatly contributes to future life success of students.

In order to realise a firm bond between family and school, it is important for the teachers to have a positive attitude, show initiative and readiness for building cooperative relationships (Shu, 2019). The onset of quality cooperation must be formed as early as at faculties, during studying. Precisely for this reason it was challenging for us to examine the way students, future teachers, assess their competences for cooperation with parents of their future students. The research results point to high self-assessment of the students, but also indicate there is room for possible improvements. In the results of her research, Zygmunt-Fillwalk (2006) pointed out the importance of implementing appropriate education of future teachers who, after a 16-weeks course, have significantly positively changed their perception of the importance, feasibility and level of preparation regarding family involvement strategies. Thus, it is necessary for faculties educating future teachers to introduce obligatory courses which would sensitise and capacitate them for more efficient cooperation with parents.

\section{References}

Alaçam, N., \& Olgan, R. (2017). Pre-service early childhood teachers' self-efficacy beliefs towards parent involvement. Teaching Education, 28(4), 1-14. DOI: https://doi.org/10.1080/10476210.2017.1324843

Avvisati, F., Gurgand, M., Guyon, N., \& Maurin, E, (2014). Getting Parents Involved: A Field Experiment in Deprived Schools. The Review of Economic Studies, 81(1), 57-83. DOI: http://dx. doi.org/10.1093/restud/rdt027

Baum, A. C., \& McMurray-Schwarz, P. (2004). Preservice teachers' beliefs about family involvement: Implicatons for teacher education. Early Childhood Education Journal, 32(1), 57-61.

Blažević, I. (2016). Suvremeni kurikul i kompetencijski profil učitelja. Zbornik radova Filozofskog fakulteta u Splitu, 6-7, 189-210.

Burcu, S., \& Sungur, S. (2009). Parental influences on Students' Self-concept, Task Value Beliefs, and Achievement in Science. The Spanish Journal of Psychology, 12, 106-117.

Cheung, S. K., \& Kam, C. S. (2019). Hong Kong pre-service early childhood teachers' attitudes towards parental involvement and the role of their family relationship quality. Journal of Education for Teaching, 45(4), 417-433. DOI: https://doi.org/10.1080/02607476. 2019.1639261

Cindrić, M., Miljković, D., \& Strugar, V. (2010). Didaktika i kurikulum. Zagreb: IEP-D2.

Domina, T. (2005). Leveling the home advantage: Assessing the effectiveness of parental involvement in elementary school. Sociology of Education, 78(3), 233-249.

Epstein, J. L. (1994). Theory to practice: Schools and family partnerships lead to school improvement and student success. In C. L. Fagnano \& B. Z. Werber (Eds.), School, 
family, and community interaction: A view from the firing lines (pp. 39-52). Boulder, CO: Westview.

Epstein, J. L. (2001). School, family, and community partnerships - Caring for the children we share. In J. L. Epstein (Ed.), School, family, and community partnerships: Preparing educa-tors and improving schools (pp. 403-426). Boulder, CO: Westview.

Fan, W., \& Williams, C. M. (2010). The effects of parental involvement on students' academic self-efficacy, engagement and intrinsic motivation. Educational Psychology, 31(1), 53-74.

Garbacz, S. A., Zerr, A. A., Dishion, T. J., Seeley, J. R., \& Stormshak, E. (2018). Parent educational involvement in middle school: Longitudinal influences on student outcomes. The Journal of Early Adolescence, 38(5), 629-660. DOI: https://doi.org/10.1177/02724 31616687670

Hiatt-Michael, D. B. (2001). Schools as Learning Communities: A Vision for Organic School Reform. School Community Journal, 11(2), 93-112.

Hill, N., \& Taylor, L. (2004). Parental School Involvement and Children's Academic Achievement: Pragmatics and Issues. Current Directions in Psychological Science, 13(4), 161-164. DOI: http://www.jstor.org/stable/20182940.

Jeynes, W. (2012). A Meta-Analysis of the Efficacy of Different Types of Parental Involvement Programs for Urban Students. Urban Education, 47(4), 706-742. DOI: http://dx.doi.org/10.1177/0042085912445643.

Jurčić, M. (2012). Pedagoške kompetencije suvremenog učitelja. Zagreb: Recedo.

Kostović-Vranješ, V., \& Ljubetić, M. (2008). "Kritične točke" pedagoške kompetencije učitelja. Život i škola, 20(2), 147-162.

LaRocque, M., Kleiman, I., \& Darling, S. M. (2011). Parental Involvement: The Missing Link in School Achievement. Preventing School Failure, 55(3), 115-122.

Ljubetić, M., \& Zadro, S. (2009). Samoprocjena kompetentnosti učitelja za pedagoški rad s roditeljima. Školski vjesnik, 58(1), 33-48.

Maleš, D. (1996). Od nijeme potpore do partnerstva između obitelji i škole. Društvena istraživanja, 5(21), 75-88.

Maleš, D. (2015). Partnerstvom obitelji i škole do uspješnog odgojno-obrazovnog rada. U S. Opić, V. Bilić i M. Jurčić (Ur.), Odgoj u školi (str. 45-74). Zagreb: Učiteljski fakultet Sveučilišta u Zagrebu.

Pendergast, D., Garvis, S., \& Keogh, J. (2011). Pre-Service Student-Teacher Self-efficacy Beliefs: An Insight Into the Making of Teachers. Australian Journal of Teacher Education, 36(12), 45-57.

Rečić, M. (2006). Kako mogu surađivati sa školom. Đakovo: Tempo.

Sheridan, S. M., Witte, A. L., Holmes, S. R., Coutts, M. J., Dent, A. L., Kunz, G. M., \& Wu, C. R. (2017). A randomized trial examining the effects of Conjoint Behavioral Consultation in rural schools: Student outcomes and the mediating role of the teacherparent relationship. Journal of School Psychology, 61, 33-53. DOI: https://doi.org/10.1016/j.jsp.2016.12.002

Shu, Z. (2019). Chinese Teachers' Perceptions of School Family Collaboration: A Study of Elementary Schools in Zhejiang Province. Educational Planning, 26(1), 23-41.

Tichenor, M. S. (1998). Preservice teachers' attitudes toward parent involvement: Implications for teacher education. The Teacher Educator, 33(4), 248-259. DOI:10.1080/08878739 809555178 
Đuranović et al., 2021. Teacher Education Students' Self-Assessment of Competence for Cooperation with Parents

Wang, M., \& Sheikh-Khalil, S. (2014). Does parental involvement matter for student achievement and mental health in high school? Child Development, 85(2), 610-625. DOI: http://dx.doi.org/10.1111/cdev.12153.

Zrilić, S., \& Marin, K. (2019). Kompetencije u suvremenoj školi - potrebe prakse iz perspektive učitelja. Školski vjesnik, 68(2), 389-400.

Zygmunt-Fillwalk, E. M. (2006). The Difference a Course Can Make: Preservice Teachers' Perceptions of Efficacy in Working with Families. Journal of Early Childhood Teacher Education, 27(4), 327-342. DOI:10.1080/10901020600996026 